\title{
sciendo
}

CIVIL AND ENVIRONMENTAL ENGINEERING REPORTS

E-ISSN 2450-8594

CEER 2020; 30 (4): 0173-0187

DOI: 10.2478/ceer-2020-0058

Original Research Article

\section{AN INNOVATIVE PROCESS FOR EFFICIENT DATA EVALUATION IN AN ATMOSPHERIC GEOCHEMICAL SURVEY OF CONTAMINATED SOIL}

\author{
Erika SKVAREKOVA ${ }^{1 *}$, Gabriel WITTENBERGER ${ }^{1}$, Andrea SENOVA ${ }^{1}$, \\ Tomas BAKALAR ${ }^{1}$, Rastislav HARCARUFKA ${ }^{2}$ \\ ${ }^{1}$ Faculty of Mining, Ecology, Process Control, and Geotechnologies; Institute of Earth's \\ resources, Department of Mountainous Sciences, Technical University of Kosice \\ ${ }^{2}$ Telegrafia a.s., Kosice
}

\begin{abstract}
The article focuses on the field of innovative trends for efficient data processing in the conduct of research of organic soil pollution using a soil air analyzer for surveys of soil contamination in situ at industrial enterprises in Slovakia. The content of the article is a discourse of theoretical knowledge from the field of the geological environment; the authors' own survey to monitor the processing and evaluation of the measured values obtained (e.g., $\mathrm{CO}_{2}, \mathrm{CH}_{4}, \mathrm{NEL}, \mathrm{BTEX}$ ). Currently, standard data processing procedures using the software that is supplied have basic or limited functionality, and the processing time is several hours, including manual and repetitive tasks. As we present in the article, the new Windows PowerShell tool is being used more efficiently, reducing the data processing time which represents an $86 \%$ time saving. There is currently no suitable or faster way of evaluating the measured data in Slovakia and the Czech Republic.
\end{abstract}

Keywords: analyzer, soil contamination, data processing, Windows Power Shell, environment

\footnotetext{
${ }^{1 *}$ Corresponding author: Technical University of Kosice, Faculty of Mining, Ecology, Process Control, and Geotechnologies; Institute of Earth's resources, Department of Mountainous Sciences, Park Komenskeho 19, 04001 Kosice, Slovakia; phone: +421 55 6023148; e-mail: erika.skvarekova@tuke.sk
} 


\section{INTRODUCTION}

Soil pollution, caused by human activity, may be a serious risk to human health, the environment, groundwater, and soil. The diagnosis of early-stage ecosystem damage is an important task from the perspective of preventive measures against toxic impacts [24,12]. In plants, toxins may cause necrosis and death. The surface of the Earth is under the continuous influence of environmental factors - both natural and anthropogenic. A significant impact on the environment can be noted in areas adjacent to metal industry plants as a consequence of pollutant emissions, especially dusts containing heavy metals, into the atmosphere [16]. Radziemska deals with the evaluation of phytostabilization strategies for the treatment of contaminated soil. From the results of her study using spectrophotometry, it was possible to clarify the benefits or potential risks resulting from the application of mineral supplements in the remediation of contaminated soil [25].

The problem of organic soil pollution in sources $[20,4]$ serves as a reminder that terrestrial oil spills are particularly hazardous if untreated as they can contaminate soils and sediments and persist in producing harmful effects for many decades. Gaseous compounds found in the porous environment of soils and rock formations may be polluted by organic matter. The presence and movement of these substances can be detected by atmospheric geochemical prospecting such as Soil Gas Surveys, which are used as a screening tool for contaminants in the soil. This process consists not only of the atmospheric geochemical prospecting but also of preparing a report containing outputs from the measurements. In this study, the processing of data gained from atmospheric geochemical prospecting was realized using an analyzer (Ecoprobe 5). Data on the spreading of contaminants into the soil air and other relevant parameters of soil air such as oxygen, carbon dioxide, and temperature were obtained. A detailed report on soil air measurements was then prepared including outputs and charts from individual measurements. Because processing is time-consuming, a novel data processing automation of atmospheric geochemical prospecting with a particular analyzer is discussed [9]. The analyzer can also be used for monitoring gas migration from a reaction zone towards the surface to detect leakages and to assess chemical hazards on the surface in the identification and quantification of chemical hazards during a fieldscale experiment on underground coal gasification [14]. The analyzer was used for measurements of $\mathrm{CO}_{2}$ and $\mathrm{O}_{2}$ levels in air from the soil found on the oil-shaleash waste pile in Kvarntorp, Sweden, with elevated uranium concentration [15]. The temperature and respiratory gas evolution in the core of the composting material was also monitored daily using the analyzer during the whole composting process [6]. The content of methane was measured by the analyzer in the methane production of two synthetic Organic Fractions of Municipal Solid Waste with different lignocellulosic content by assessing microwave and autoclave pre- 
treatments and the content of methane and carbon dioxide in methane oxidation under landfill covers, and the contribution of methane to the above atmospheric carbon dioxide levels $[23,30,1]$. VOCs were monitored by the analyzer in the study of pollution at a site polluted mainly by recalcitrant psychopharmaceuticals and monoaromatic hydrocarbons such as benzene, toluene, and chlorobenzene [19]. These applications show a variety of analyzer applications in practice, but they say nothing of the data processing which may be time-consuming, as previously mentioned. For this reason, it is necessary to introduce innovative methods and automation systems for better time management where possible[ 7,8$]$.

\section{MATERIALS AND METHODS}

\subsection{Experimental measurement using the analyzer}

The analyzer is a highly sensitive portable multifunction gas analyzer for in-situ soil contamination surveys. It has the ability to provide optimum performance and flexibility for efficient, inexpensive contamination surveys and monitoring of volatile organic compounds, e.g., light non-aqueous phase liquid (LNAPL), benzene, toluene, ethylbenzene, and xylene, in soil (Fig. 1).

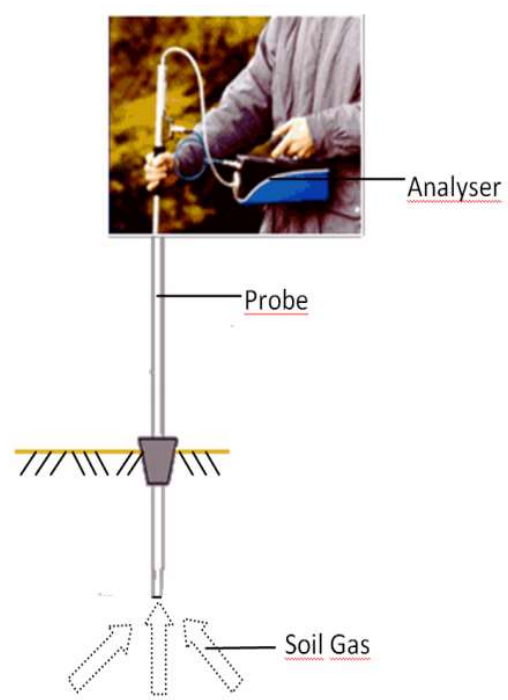

Fig.1. Analysis of soil gas pollution Source: RS Dynamics, 2015

In the environment, the most widely spread LNAPLs are polycyclic aromatic hydrocarbons (PAHs) [13]. It is also probable that due to increasing mineral oil production and transport, the pollution of water, soil, and sediment by PAHs will 
continue to grow $[10,18]$. In the environment, PAHs are subject to volatilization, photo-oxidation, chemical oxidation, adsorption on soil particles, and leaching [3]. In this study, the analyzer was used to detect the presence of organic compounds in the soil. It is composed of two independent analytical systems; a Photo-ionization analyzer (PID) and an Infra-red analyzer (IR). The PID measures the total level of VOCs and other toxic gases, including chlorinated hydrocarbons to $\mathrm{ppb}$ levels with a wide dynamic range $(0.1 \mathrm{ppb}$ to $4000 \mathrm{ppm})$. The IR comprises four independent channels for the selected analysis of methane, petroleum hydrocarbons, $\mathrm{CO}_{2}, \mathrm{~N}_{2} \mathrm{O}$, and $\mathrm{H}_{2} \mathrm{~S}$ with ppm resolution. The analyzer also reads oxygen, soil temperature, sampled gas temperature, and ambient pressure/sampling vacuum [27].

\subsection{The standard data processing}

The measured data is usually processed by standard software, supplied as part of the measuring equipment, or downloadable from the manufacturer's website. This software provides basic (i.e., limited) functionality, for example, data transfer into a computer, data processing, and results saved in predefined text or graphic form, and export and import data in a predefined format (CSV or similar) [26]. In the case of large-scale measurements - often dozens of measurements with tens or hundreds of data -the processing of hundreds and thousands of items is required, which typically need to be held in output reports. In this case, the core functionality of the basic programs is required to perform a lot of other work, often just of a manual nature, but nevertheless, lengthy and requiring intense attention. Typical solutions in these situations are [2]:

- using standard software - strenuous solution, which requires further manual, repetitive, and time-consuming tasks for the processing of data, and often hard work organizing the results into a final report, usually only by manual copying and pasting of data, images, or screenshots.

- using features of standard software for exporting and importing data, for example, in CSV format, and the processing of exported data in spreadsheets or specific computer programs such as Matlab or similar.

This solution reduces labor intensity but brings further adjustments and adaptations to accommodate the processing software (e.g., macros). The Windows operating system and office tools such as Microsoft Office provide a variety of different instruments and components for the automation of pre-processing and processing of the data from measurements. Particularly suitable are:

- Macros and Visual Basic for Applications (VBA) tools in Microsoft Office,

- Windows PowerShell.

The program Ecoprobe Vie Plus provides data transfer from the measuring instrument (Fig. 2). 
INNOVATIVE PROCESS FOR EFFICIENT DATA EVALUATION IN ATMOSPHERIC 177 GEOCHEMICAL SURVEY OF CONTAMINATED SOIL

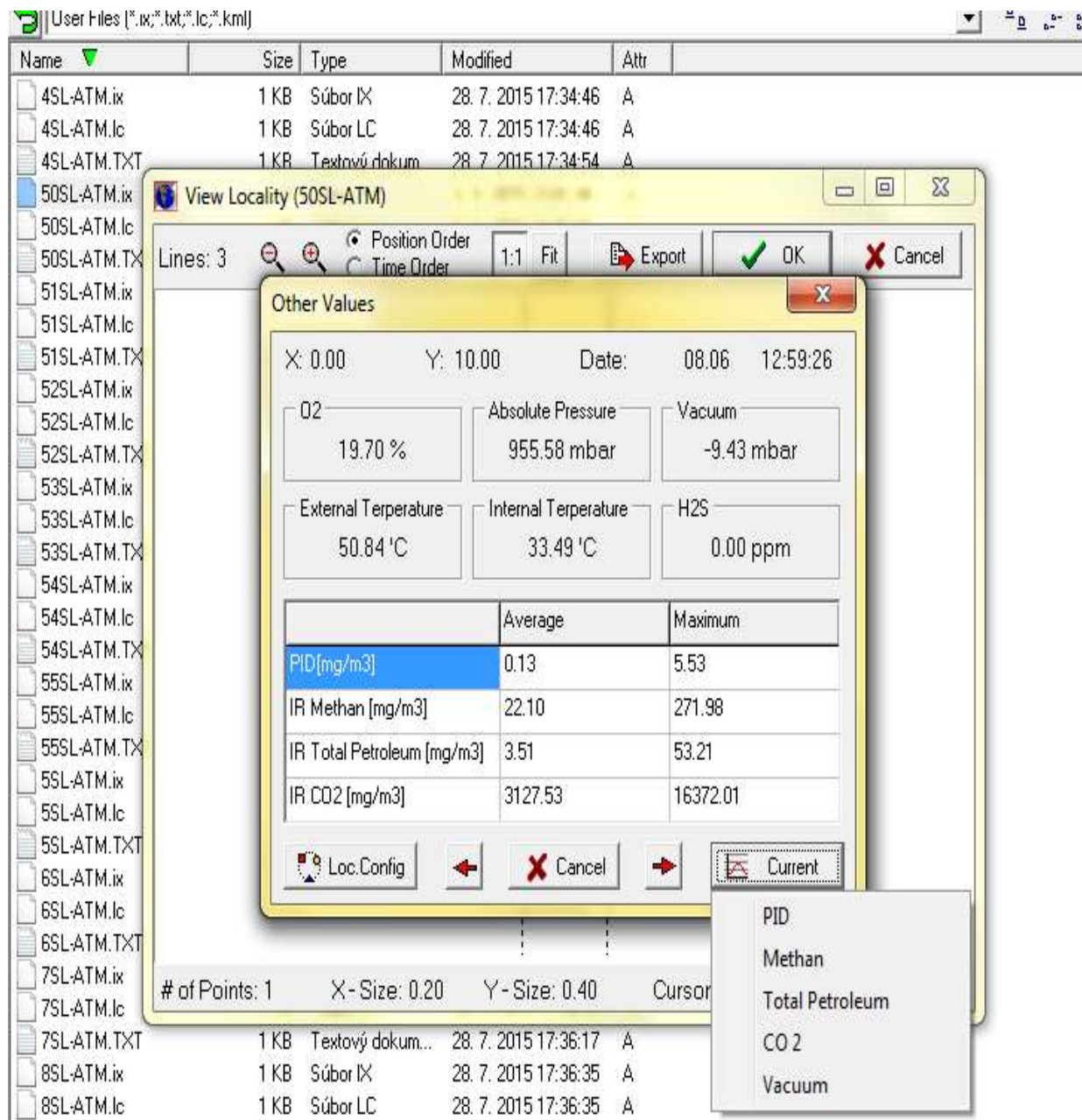

Fig. 2. Transfer of data from analyzer to computer Source: own resource 
This software allows viewing of tabular and graphical representations of the measured values (Fig. 3), calibration procedures, and communication between the analyzer and a computer. Data may be shown on a 3D map using Surfer, Rockware, or Matlab software. The program requires a computer with a $486 \mathrm{Mbps}$ processor or higher, operating system Windows 2010/NT4.0, at least 16 MB of system memory, and $25 \mathrm{MB}$ of free hard disk space.

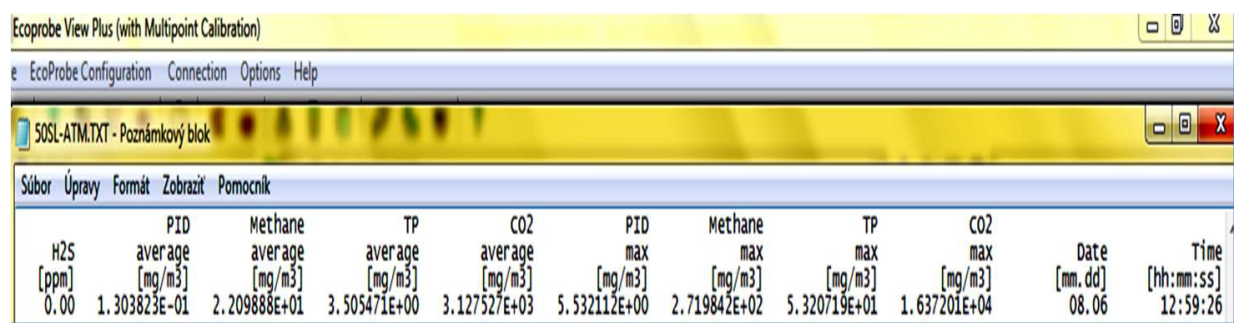

Fig. 3. View of the transmitted data from analyzer to a computer in a txt file Source: own resource

\subsection{Processing of measured data under standard processing}

For comparison, the processing of the data of soil gas measured using an analyzer for Windows 2010 was presented on chosen localities of the Slovak Republic in 2014. The measurements were performed at three locations, in 175 boreholes, with six measurements in each borehole (at a depth of about $70 \mathrm{~cm}$ ), i.e., there were $175 \times 6=1050$ measured data stored in 175 files.

The processing of these measurements can be divided into:

- The measurements of values - one borehole for about $35 \mathrm{~min}$, i.e., the measuring process lasted for about 102 hours,

- The processing of measured data which includes:

- The data transfer to computer, 11 borehole data per $10 \mathrm{~min}$, i.e., about 2.5 hours total,

- The data processing in the form of charts and tables for about 24 hours,

- The processing of the final report for about 32 hours.

The total time required to accomplish the whole project without transportation and idle time is about 160.5 hours. Mechanical, monotonous work without data transfer and processing automation from the device to the computer constituted almost $36.5 \%$ of the work.

The tools in the Microsoft Office software package (such as Access, Excel, PowerPoint, Word) - in addition to the standard functionality available by menus, commands, and toolbars- also provide macros to extend the functionality. There are controls for the recording of the sequence of commands, saving as macro commands (directly macros), and recalling these macros [29]. 


\subsection{Possibilities of automation and improvement of data processing}

Recorded macros are stored as part of the document in the form of embedded procedures containing the programming code - commands of VBA. The VBA commands are an implementation of Visual Basic for the purpose of extending the functionality of the tool. The code of the recorded macros can be extended, modified, or can be fully programmed in VBA for full custom data processing, using a wide variety of this tool's elements such as:

- Elements of the document tool such as cell(s)/area(s)/sheet(s)/function(s) in Excel, texts and paragraphs in Word, slide(s) in PowerPoint, etc.,

- Elements of the Graphical User Interface (GUI) tool, such as icons, toolbars, forms, buttons,

- Triggering - automatic starting of these embedded procedures, e.g., when opening a document, modifying, closing a paper or tool, etc.

Figure 4 illustrates an example of the VBA tools in Microsoft Excel, i.e., a document containing the macro Imp Dat.

As indicated in Fig. 4:

- Command View $>$ Macros $>$ View Macros opens the window which shows the currently available macros:

- Command Run, executes the selected macro as a sequence of commands, - Command Edit, opens Microsoft VBA in a new window.

- VBA provides tools for the preparation of macros - creation, modification, debugging, running, etc.

This feature is a standard part of the operating system Windows has intended for the automation of control in the Windows environment. It is primarily used for the automation of administrator activities and tasks but can also be used for other purposes, i.e., for pre-processing and processing of measured data [21]. 


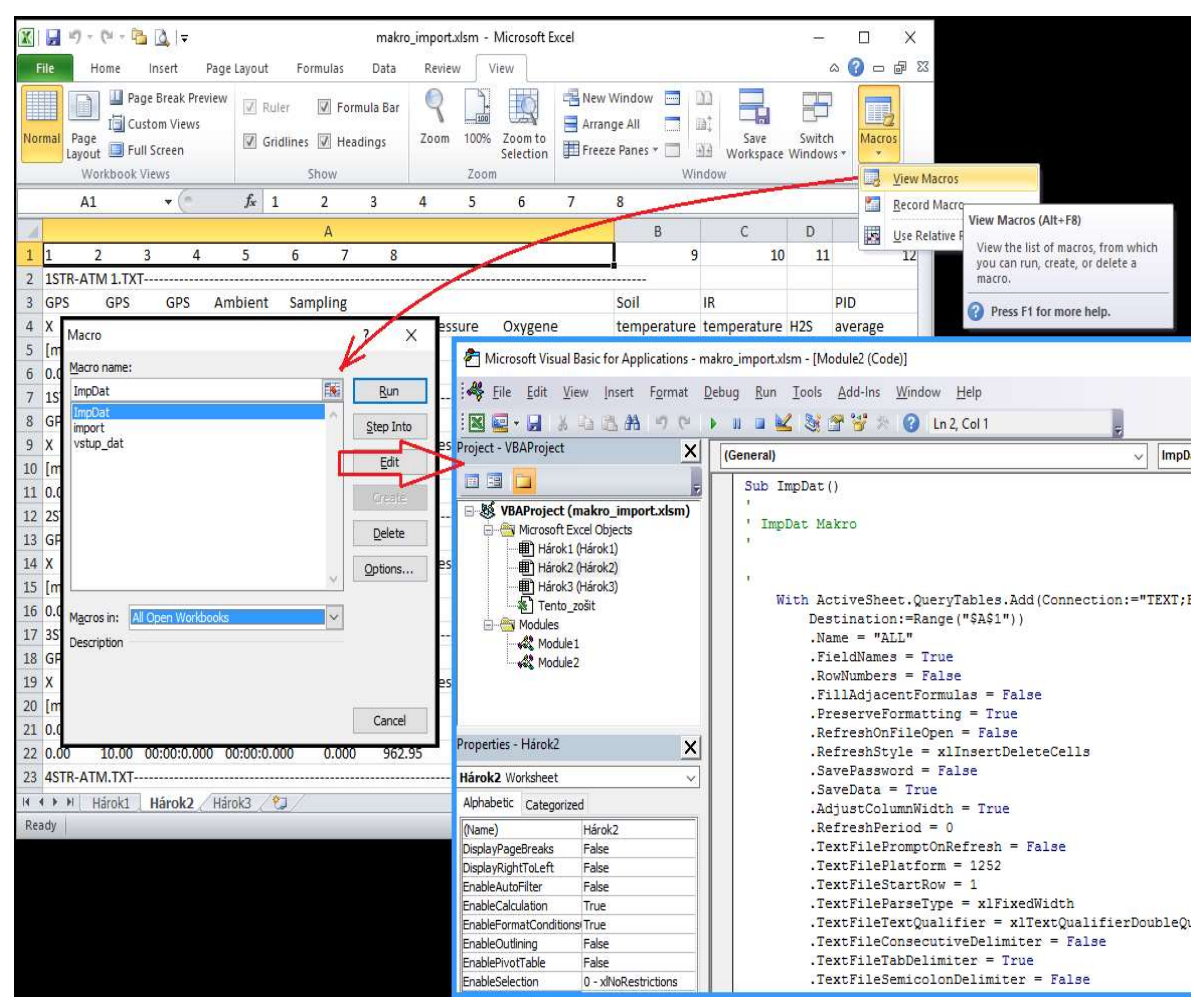

Fig. 4. Example of macros and VBA in Microsoft Excel Windows PowerShell Source: Birnbaum, 2003

Windows PowerShell enables the creation and execution of scripts - ordinary textual files (plain text) containing PowerShell commands, using the file extension .PS1. The text file is a "program" provided by this feature. Windows PowerShell is available through the console (host), in which commands can be entered directly (interactive) or run from scripts. There are two types of console [5,11]:

- An alphanumerical (command-line) console (Fig. 5),

- A graphical - Integrated Scripting Environment (ISE) console, presenting an advanced set of tools and features (Fig. 6). 
INNOVATIVE PROCESS FOR EFFICIENT DATA EVALUATION IN ATMOSPHERIC GEOCHEMICAL SURVEY OF CONTAMINATED SOIL

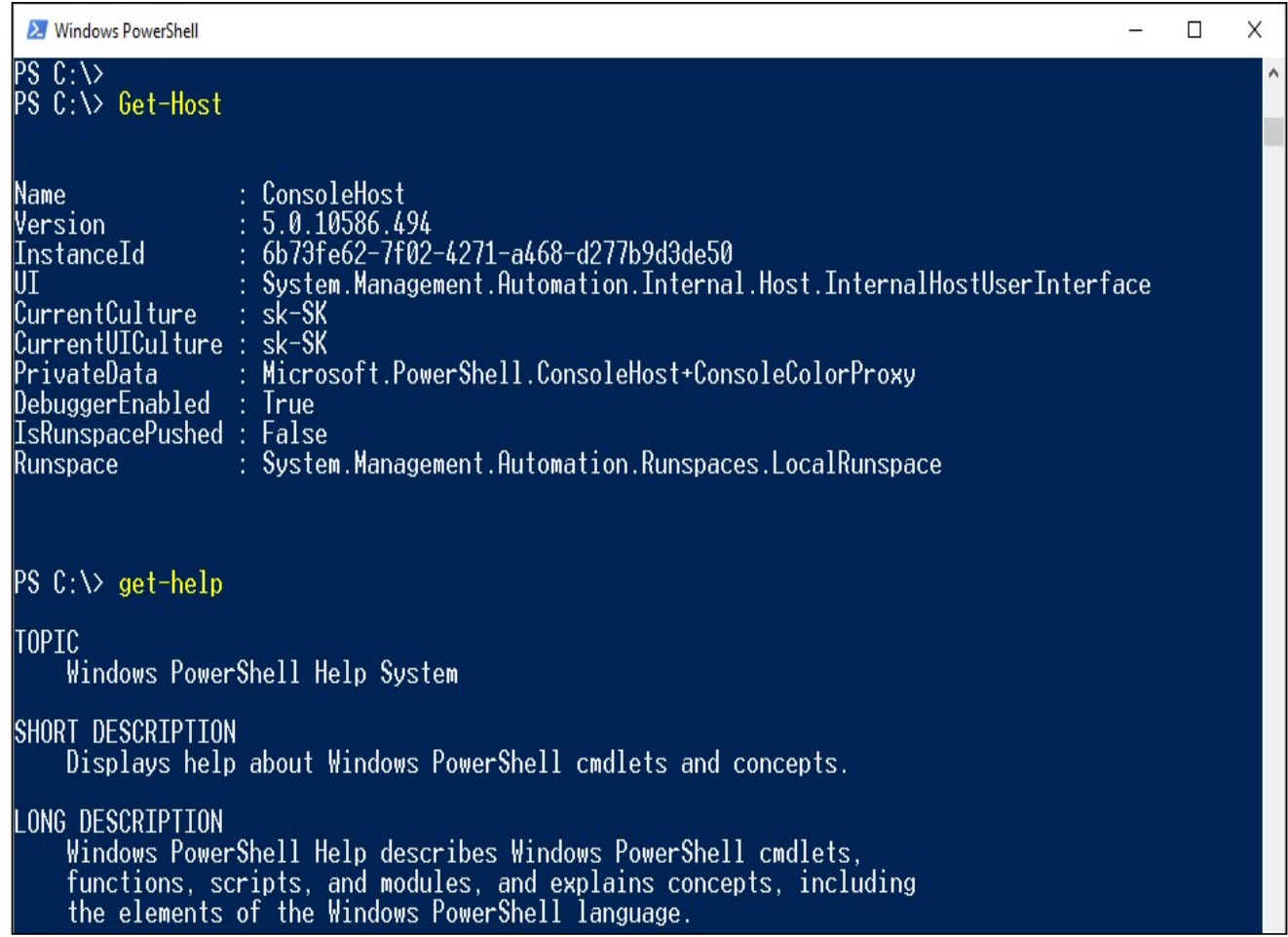

Fig. 5. Example of Windows PowerShell command-line console Source: Harshul, 2016 


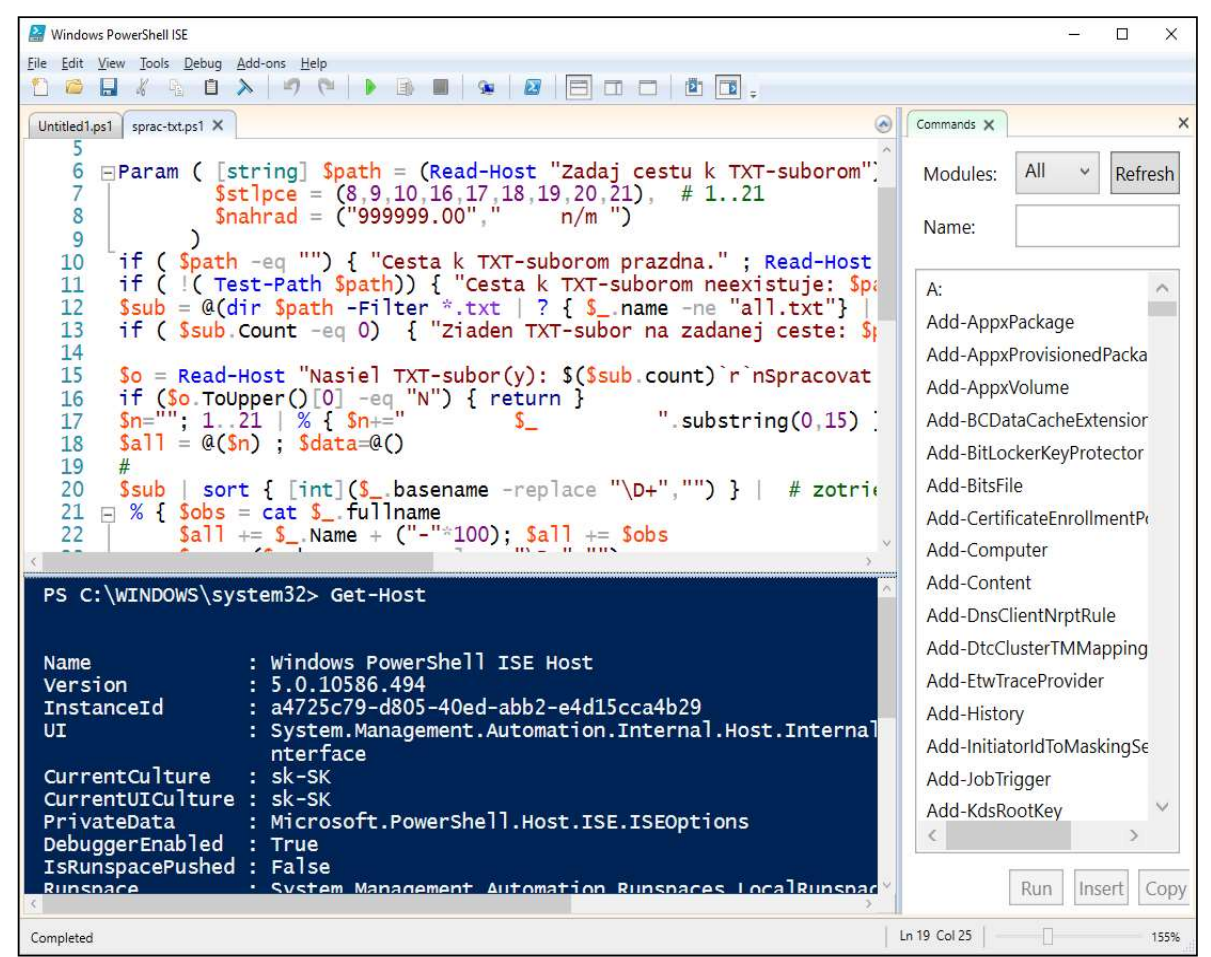

Fig. 6. Example of Windows PowerShell graphical console ISE Source: Lee et al., 2011

Windows PowerShell offers a vast range of features and possibilities. It includes built-in help, which provides and describes everything necessary for working with this technology.

Basic commands are, e. g.:

- Get-Help - built-in help,

- Get-Command - available commands (all or selected),

- Get-Module - available PowerShell modules (with further commands) [17]

\section{RESULTS}

As mentioned above, the standard processing of the measurements required to process 175 files, i.e., 175 times repeating of file opening, data selection, transfer into another program, and data preparation. The standard processing means tedious manual and mechanical work with necessary and essential intense 
attention as any errors at this stage can have a substantial impact on results. The specific Windows PowerShell script has been created (Fig. 7) to improve this process. This script has performed the standard processing automatically, has read the specified file (s), has selected the specified data, processed them into the required format, and stored it in one single data file. This data could be utilized not only in one step but also in combination with, e.g., a macro in Microsoft Office [22]. On running the script, it reads the data file(s) of the measurements in the specified path, processes them by selecting and arranging data, and generates two output files (Fig. 8):

- DATA.TXT - contains data for import,

- ALL.TXT - contains data for checking and inspection.

Note: This script has regarded as the authors' copyright work

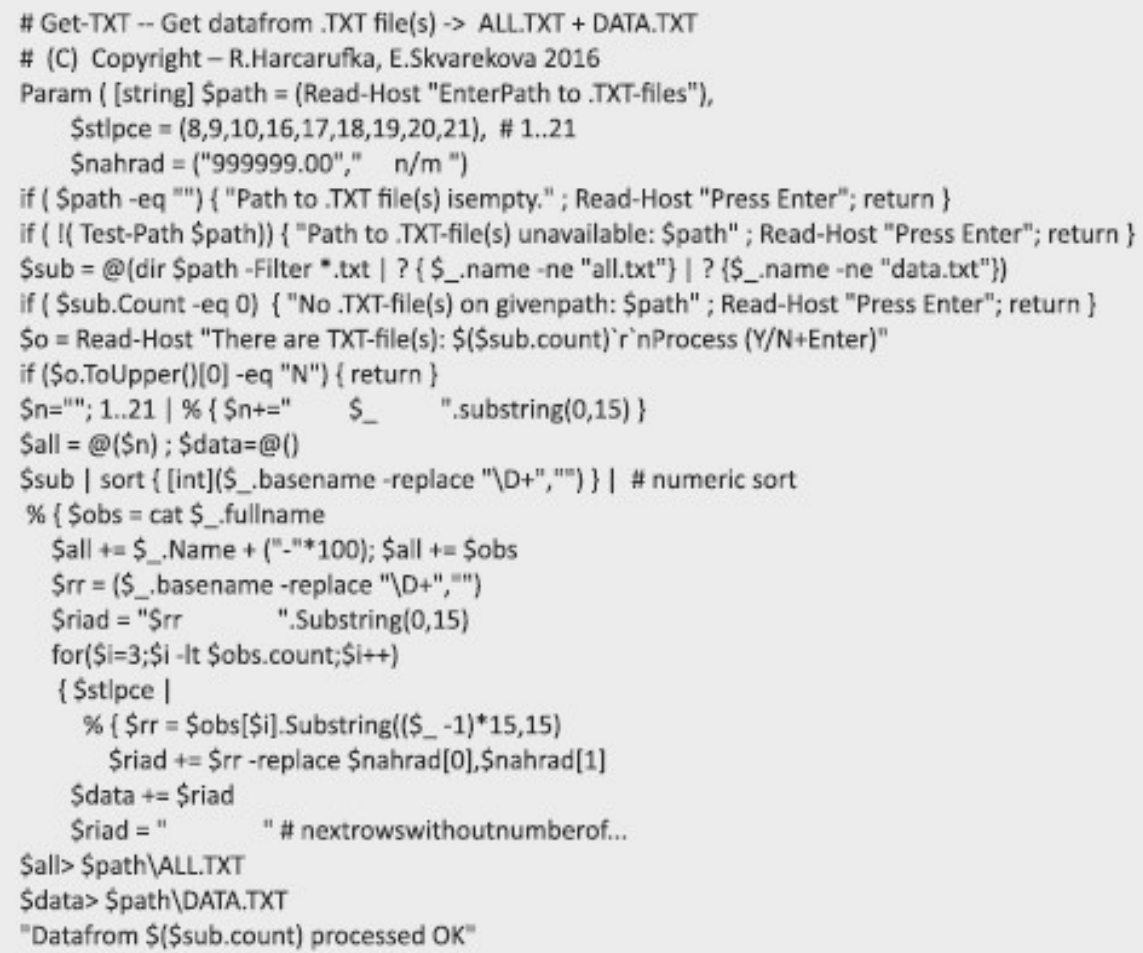

Fig. 7. Source code of the script to automate the data processing

Source: own resource 


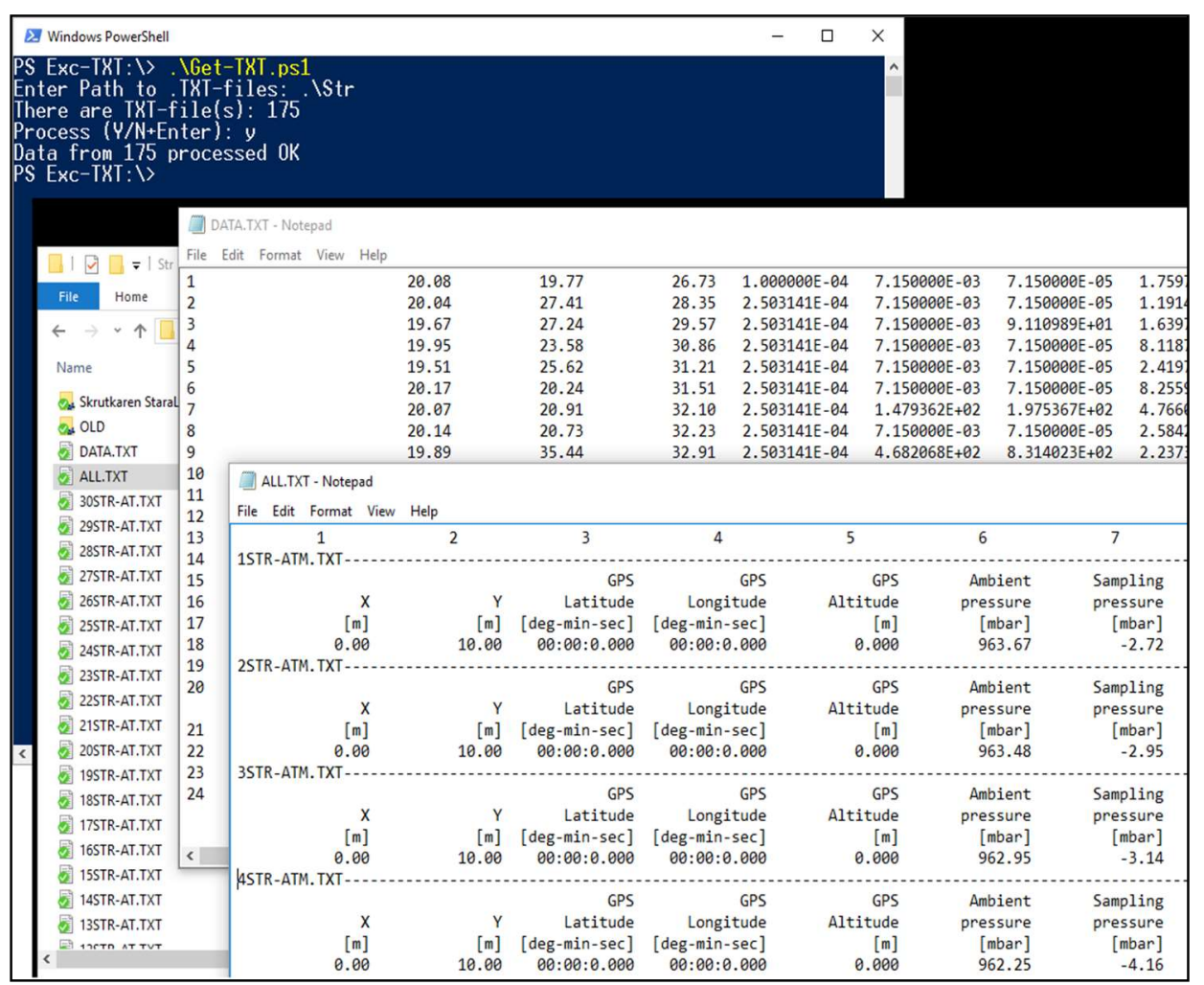

Fig. 8. Practical example of the text and results

Source: own resource

\section{DISCUSSION}

The above processing of $175 \times 6=1050$ measured data in 175 files, which took approximately 160.5 hours under manual processing, can clearly be significantly improved and the processing time greatly reduced. The time of manual in-situ measurements is probably 102 hours, which is the same as for the standard data processing; however, the processing time of the measured data has been reduced to 8 hours by implementing the above script. The process includes the following procedures: data transfer to a computer, data processing in tables, graphs, final report.

Thus, the total time required to accomplish this project without transportation and idle time is probably 110 hours. The mechanical and monotonous work constituted a maximum of $8 \%$ of the work. 


\section{CONCLUSIONS}

The article demonstrates the possibilities for improving the processing of measured data based on standard technologies available in Windows environments (Windows PowerShell), in particular, Microsoft Office tools (macros, VBA), which were the subject of study in our paper. Research, design, and implementation of the solution was carried out to improve the data processing and automation of measurements. Although scripts generally run slower than compiled programs, the purpose of data transfer within them is sufficient and the preparation of a script and its modification is much easier than the compilation of a program. The script presented in the paper led to significant savings in time as well as increasing the reliability of the data pre-processing and processing. Although the paper presents a solution in a specific set of measurements, the suggested methodology and the process of implementation can be applied generally in order to replace manual and repetitive activities. In the standard case, the data transfer from the device (analyzer) to the computer took 58.5 hours by manual processing of measured data. Using the novel Windows PowerShell script, this time was shortened to 8 hours giving a saving of $86 \%$ of the time otherwise taken, and also saving energy consumption [28]

Acknowledgments: This paper was supported by The Survey of the portable environmental burden at the industrial enterprises: Strihovce, the chemical warehouse of the former VD Vihorlat; Skrutkáreň EXIM a.s., Stará Lubovňa; Kovohuty a.s. Krompachy No. HZ- P- 101-0020/15 and the Scientific Grant Agency of the Ministry of Education of the Slovak Republic under grant VEGA 1/0651/2018 - Research on institutional environment influence to the corporate social responsibility, consumers satisfaction, and performance of the company.

\section{REFERENCES}

1. Alcani, M, Dorri, A and Maraj, A 2018. Estimation of energy recovery potential and environmental impact of Tirana landfill gas, Environment Protection Engineering, 44 (3), 117-128.

2. Arpaia, P, De Matteis, E and Inglese, V 2015. Software for measurement automation: A review of the state of the art. Measurement, 66, 10-25.

3. Arun, A, Raja, PP, Arthi, R, Ananthi, M, Kumar, KS and Eyini, M 2008. Polycyclic aromatic hydrocarbons (PAHs) biodegradation by basidiomycetes fungi, Pseudomonas isolate, and their cocultures: comparative in vivo and in silico approach. Applied Biochemistry and Biotechnology, 151, 132-142. 
4. Bartha $\mathrm{R}$ and Bosser, I 1984. The treatment and disposal of petroleum refinery wastes. In Petroleum Microbiology, Macmillan: New York, NY, USA, 553-577.

5. Birnbaum, D 2003. Microsoft Excel VBA Professional Projects. Cengage Learning.

6. Covino, $\mathrm{S}$ et al. 2016. Polycyclic aromatic hydrocarbons degradation and microbial community shifts during co-composting of creosote-treated wood. Journal of Hazardous Materials, 301, 17-26.

7. Chang, W and Wuj, J 2016. An innovative optical-based method and automation system for rapid and non-destructive measurement of the web thickness of microdrills, Measurement 94, 388-405.

8. Flegner, P, Kačur, J, Durdán, M, Leššo, I and Laciak, M, 2014. Measurement and processing of vibro-acoustic signal from the process of rock disintegration by rotary drilling. Measurement, 56, 178-193.

9. Flimel, M 2012. Analysis of selected ergonomic problems of left- handed workers in production activity In: Annals of Faculty of Engineering Hunedoara. 10, 2, 83-86.

10. Haritash, AK, Kaushik and CP 2009. Biodegradation aspects of polycyclic aromatic hydrocarbons (PAHs), a review, Journal of Hazardous Materials, 169, $1-15$.

11. Harshul, P 2016. Instant Windows PowerShell Guide. Puckt Publishing Ltd., India.

12. Huo, D, Wu, J, Kong, Q, Zhang, GB, Wang, YY and Yang, HY 2018. Macromolecular toxins secreted by botrytis cinerea induce programmed cell death in arabidopsis leaves. Russian Journal of Plant Physiology, 65, 579587.

13. Kadri, T, Rouissi, T, Brar, SK, Cledon, M, Sarma, S and Verma, M 2017. Biodegradation of polycyclic aromatic hydrocarbons (PAHs) by fungal enzymes, A review, Journal of Environmental Sciences , 51, 52-74.

14. Kapusta, K, Staňczyk, K, Wiatowski, M and Chećko, J 2013. Environmental aspects of a field-scale underground coal gasification trial in a shallow coal seam at the Experimental Mine Barbara in Poland, Fuel 113, 196-208.

15. Kastlander, J, Aldener, M, Frittioff, T, Raghoo, L and Purtschert, R 2019. Measurement of radioxenon and radioargon in air from soil with elevated uranium concentration, Journal of Environmental Radioactivity, 197, 62-66.

16. Kostecki, J, Greinert, A, Drab, M, Wasylewicz, R, Walczak, B 2015. Chemical soil degradation in the area of the Głogów copper smelter protective forest. Civil and Environmental Engineering Reports, 2 (17), 6771.

17. Lee, T, Mitschke, K, Schill, M and Tanasovski, T 2011. Windows PowerShell 2.0 Bible, 1 st ed.; John Wiley \& Sons, UK. 
18. Liwarska-Bizukojc, E, Andrzejczak, O and Solecka, M 2019. Study on activated sludge flocs morphology and composition in a full-scale wastewater treatment plant in Poland. Environment Protection Engineering, 45 (2), 69-82.

19. Lhotský, O et al. 2017. Pharmaceuticals, benzene, toluene and chlorobenzene removal from contaminated groundwater by combined $\mathrm{UV} / \mathrm{H}_{2} \mathrm{O}_{2}$ photooxidation and aeration, Water Research 120, 245-255.

20. Murray, ML, Poulsen, SM and Murray, M 2020. Decontaminating Terrestrial Oil Spills: A Comparative Assessment of Dog Fur, Human Hair, Peat Moss and Polypropylene Sorbents. Environments 7, 52

21. Orin, T 2017. Windows Server 2016 Inside Out, (includes Current Book Service), 1 st ed. Microsoft Press.

22. Payette, B and Siddaway, R 2017. Windows PowerShell in Action, 3rd Edition; Manning Publications, USA.

23. Pecorini, I, Baldi, F, Carnevale, EA and Corti, A 2016. Biochemical methane potential tests of different autoclaved and microwaved lignocellulosic organic fractions of municipal solid waste, Waste Management 56, 143-150.

24. Polyakova, G, Pashenova, N, Senashova, V and Kudryashev, N 2020. Pine Stands as Bioindicators: Justification for Air Toxicity Monitoring in an Industrial Metropolis. Environments 7(4), 28.

25. Radziemska, M 2017. Aided phytostabilization of copper contaminated soils with 1. perenne and mineral sorbents as soil amendments, Civil and Environmental Engineering Reports, 3 (26), 79-89.

26. Rimár, M, Kulikov, A, Fedák, M, Khovanskyi, S and Pavlenko, I 2020. Application of the cfd software for modeling thermal comfort in sport hall, MM Science Journal. Prague, MM Publishing, 3723-3727.

27. RS Dynamics, 2015. Ecoprobe5.

28. Škvareková, E 2015. Prieskum pravdepodobnej environmentálnej zátaže na lokalitách: Strihovce, sklad chemikálií bývalého VD Vihorlat, Skrutkáreň EXIM a.s.- Stará Lubovňa, Kovohuty a.s., Krompachy SprávaAtmogeochemické merania pôdneho vzduchu/ - Košice : TU, 115.

29. Šofranko, M, Wittenberger, G and Škvareková, E 2015. Optimisation of technological transport in quarries using application software. Journal of Mining and Mineral Engineering 6, 1-13.

30. Widory, D, Proust, E and Bellenfant, G 2012. Bour, O. Assessing methane oxidation under landfill covers and its contribution to the above atmospheric $\mathrm{CO} 2$ levels: The added value of the isotope $(\delta 13 \mathrm{C}$ and $\delta 180 \mathrm{CO} 2 ; \delta 13 \mathrm{C}$ and $\delta$ D CH4) approach. Waste Management 32, 1685-1692.

Editor received the manuscript: 08.10.2020 